Atmos. Chem. Phys., 10, 919-929, 2010

www.atmos-chem-phys.net/10/919/2010/

(C) Author(s) 2010. This work is distributed under

the Creative Commons Attribution 3.0 License.

\title{
Acetaldehyde in the Alaskan subarctic snowpack
}

\author{
F. Domine ${ }^{1,2}$, S. Houdier ${ }^{1,2}$, A.-S. Taillandier ${ }^{1,2}$, and W. R. Simpson ${ }^{3,4}$ \\ ${ }^{1}$ CNRS-INSU, UMR 5183, Laboratoire de Glaciologie et Géophysique de l'Environnement, BP 96, \\ 38402 Saint-Martin d'Hères Cedex, France \\ ${ }^{2}$ Université Joseph Fourier - Grenoble I, Grenoble, France \\ ${ }^{3}$ Geophysical Institute, University of Alaska, Fairbanks, USA \\ ${ }^{4}$ Department of Chemistry, University of Alaska, Fairbanks, USA
}

Received: 27 August 2009 - Published in Atmos. Chem. Phys. Discuss.: 23 September 2009

Revised: 12 January 2010 - Accepted: 15 January 2010 - Published: 1 February 2010

\begin{abstract}
Acetaldehyde is a reactive intermediate in hydrocarbon oxidation. It is both emitted and taken up by snowpacks and photochemical and physical processes are probably involved. Understanding the reactivity of acetaldehyde in snow and its processes of physical and chemical exchanges requires the knowledge of its incorporation mechanism in snow crystals. We have performed a season-long study of the evolution of acetaldehyde concentrations in the subarctic snowpack near Fairbanks $\left(65^{\circ} \mathrm{N}\right)$, central Alaska, which is subjected to a vigorous metamorphism due to persistent elevated temperature gradients in the snowpack, between 20 and $200^{\circ} \mathrm{C} \mathrm{m}^{-1}$. The snowpack therefore almost entirely transforms into depth hoar. We have also analyzed acetaldehyde in a manipulated snowpack where temperature gradients were suppressed. Snow crystals there transformed much more slowly and their original shapes remained recognizable for months. The specific surface area of snow layers in both types of snowpacks was also measured. We deduce that acetaldehyde is not adsorbed onto the surface of snow crystals and that most of the acetaldehyde is probably not dissolved in the ice lattice of the snow crystals. We propose that most of the acetaldehyde measured is either trapped or dissolved within organic aerosol particles trapped in snow, or that acetaldehyde is formed by the hydrolysis of organic precursors contained in organic aerosols trapped in the snow, when the snow is melted for analysis. These precursors are probably aldehyde polymers formed within the aerosol particles by
\end{abstract}

Correspondence to: F. Domine (florent@lgge.obs.ujf-grenoble.fr) acid catalysis, but might also be biological molecules. In a laboratory experiment, acetaldehyde-di-n-hexyl acetal, representing a potential acetaldehyde precursor, was subjected to our analytical procedure and reacted to form acetaldehyde. This confirms our suggestion that acetaldehyde detected in snow could be produced during the melting of snow for analysis.

\section{Introduction}

Snow is a complex multiphase medium consisting of ice crystals, interstitial air, atmospheric particles scavenged by precipitating snow or deposited by wind, and possibly liquid water and vegetal debris (Domine et al., 2008; Grannas et al., 2007). Precipitating snow crystals form distinct snow layers (Colbeck, 1991) which produce the snowpack, also called snow cover, or just snow (Domine et al., 2008). It is now well established that the snowpack is a photochemical reactor whose emissions of chemical species to the atmosphere can dramatically affect the composition of the overlying air (Domine and Shepson, 2002; Grannas et al., 2007). For example, nitrate photolysis results in the release of highly reactive molecules such as $\mathrm{NO}, \mathrm{NO}_{2}, \mathrm{HONO}$ and $\mathrm{OH}$, which considerably enhance the oxidative capacity of the atmosphere (Mauldin et al., 2001; Yang et al., 2002).

Oxidants formed by snowpack photochemistry react with organic compounds present in snow, to produce a wide variety of species such as haloalkanes (Swanson et al., 2002) organic acids (Dibb and Arsenault, 2002) and carbonyl compounds (Boudries et al., 2002; Couch et al., 2000; Grannas

Published by Copernicus Publications on behalf of the European Geosciences Union. 
et al., 2002; Guimbaud et al., 2002; Hutterli et al., 1999; Jacobi et al., 2002; Sumner and Shepson, 1999). Among this last class, we focus our attention on aldehydes, which are intermediates in hydrocarbon oxidation processes that play a central role in atmospheric chemistry (Lary and Shallcross, 2000; Shepson et al., 1996). In particular, in polar regions, aldehydes contribute significantly to the $\mathrm{OH}$ budget (Yang et al., 2002), and they react with bromine atoms, terminating chains of reactions that destroy ozone in the polar marine boundary layer during the spring (Barrie et al., 1988; Grannas et al., 2002).

Aldehydes are not just emitted by the snowpack, they are also taken up by this medium (Grannas et al., 2002; Hutterli et al., 1999; Jacobi et al., 2002). Modeling snow-atmosphere exchanges of aldehydes therefore requires the understanding of their mechanism of incorporation in snow crystals. In principle, chemical species with a dipole moment such as aldehydes can be incorporated into snow crystals during their growth in the atmosphere (Domine et al., 1995). By dissolving within the ice crystalline lattice of the snow crystals, they form a solid solution (Thibert and Domine, 1997) with ice which isolates them from the atmosphere, limiting their reactivity with atmospheric constituents. This is thought to be the case for formaldehyde (Burkhart et al., 2002; Perrier et al., 2002). They can also adsorb onto snow crystal surfaces, therefore remaining available for reactions with atmospheric species, and this is thought to apply to acetaldehyde and heavier aldehydes (Petitjean et al., 2009; Sokolov and Abbatt, 2002). Houdier et al. (2002) suggested that acetaldehyde might also be incorporated into organic aerosols that can be scavenged by snow crystals during their growth or fall, or dry-deposited to the snow surface after precipitation. Finally, as mentioned above, aldehydes can be produced in snow after deposition by the photochemistry of heavier organic compounds (Grannas et al., 2004). Part or all of this production can then diffuse through snowpack interstitial air and be released to the atmosphere where their fluxes can be measured (Boudries et al., 2002; Couch et al., 2000; Guimbaud et al., 2002).

Most studies of the incorporation of aldehydes in snow focused on formaldehyde (Hutterli et al., 1999, 2002; Jacobi et al., 2002; Perrier et al., 2002). Conclusions as to their mechanisms of incorporation in snow are not in agreement. Some studies, backed up by laboratory experiments, concluded that $\mathrm{HCHO}$ is almost exclusively incorporated as a solute in the ice crystalline lattice (Perrier et al., 2002, 2003), while others proposed that it is also adsorbed onto snow crystal surfaces (Hutterli et al., 2002; Jacobi et al., 2002). Studies of higher aldehydes are few and deal essentially with acetaldehyde. Houdier et al. (2002) measured acetaldehyde in snow and Guimbaud et al. (2002) measured it in the overlying air at Alert $\left(82^{\circ} \mathrm{N}\right.$, Canadian high Arctic). Both studies obtained data during both the polar winter in the complete absence of sunlight and in the spring, with $24 \mathrm{~h}$ sunlight. Houdier et al. (2002) also measured snow physical properties such as temperature and specific surface area and concluded that the incorporation of acetaldehyde into snow could not be explained by a single process. They suggested that a combination of adsorption and dissolution was involved and furthermore indicated that acetaldehyde may also have been formed by a precursor in the snow, that would produce acetaldehyde when the snow was melted for analysis. They therefore did not reach any clear-cut conclusion.

Couch et al. (2000) performed gas phase measurements of acetaldehyde over and in the snowpack in Michigan $\left(47^{\circ} \mathrm{N}\right)$. They also used a flux chamber to study the kinetics of airsnow exchanges and, in contrast to Houdier et al. (2002), concluded fairly clearly that acetaldehyde was adsorbed on the surface of snow crystals.

The studies of Houdier et al. (2002) and Couch et al. (2000) reached very different conclusions, which underlines our limited understanding of the mechanism of incorporation of aldehydes in snow. This failing clearly limits our ability to understand their reactivity in snow. Since acetaldehyde behavior in snow is very likely to be affected by thermodynamic and/or kinetic processes, it is of interest to perform studies under conditions where both thermodynamic and kinetic factors are different. Fairbanks, located in the taiga of central Alaska, is an ideal location for such a new study. Unlike the Arctic snowpack at Alert (Domine et al., 2002) and the snowpack in Michigan, which is of the maritime type (Sturm et al., 1995), the subarctic snowpack near Fairbanks is almost entirely comprised of depth hoar and faceted crystals that form highly permeable, low-density snow layers (Sturm and Benson, 1997; Taillandier et al., 2006). Furthermore, subarctic snow is a better thermal insulator than its Arctic counterpart, the ground cools less in winter, and elevated thermal gradients persist in the snowpack during the whole season, generating vigorous sublimationcondensation cycles that can release species trapped in solid solution with ice. In general, the subarctic snowpack is also warmer, because basal layers remain within a few degrees of freezing (Sturm and Johnson, 1991). We therefore expect these different conditions to reveal different processes than those observed at Alert.

To further widen the range of thermodynamic and kinetic conditions affecting the snowpack, we also studied a manipulated snowpack that accumulated on tables. Air circulation under the tables greatly reduced the temperature gradient in the snowpack and therefore also reduced the dynamism of the sublimation-condensation cycles affecting the snow crystals. As a result, depth hoar did not form in that snow (Domine et al., 2007a), which evolved slowly towards rounded shapes typical of low temperature gradient metamorphism.

Our study was carried out throughout the whole winter season, from late November to early April. We studied the evolution of both formaldehyde and acetaldehyde concentrations in snow. This paper reports data on acetaldehyde. The results obtained on formaldehyde will be reported in a subsequent paper. During this study, snowpack physical 
properties were studied in detail and are reported in Taillandier et al. (2006). In particular, the specific surface area (SSA) of snow was measured throughout the season in order to test adsorption equilibria. However, gas phase acetaldehyde was not measured. To understand snow-acetaldehyde interactions, the most useful variable is the partial pressure of acetaldehyde in snowpack interstitial air, $P_{\mathrm{CH} 3 \mathrm{CHO}}$. However, in shallow seasonal snowpacks, pumping snowpack air inevitably draws air from the atmosphere, which dilutes snowpack air in a manner that is difficult to quantify because it depends on snow permeability and layering (Albert et al., 2002). The resulting large uncertainties therefore seriously limit the interest of such measurements with currently available sampling methods.

\section{Methods}

\subsection{Snowpacks studied}

Three $4 \mathrm{~m} \times 2 \mathrm{~m}$ tables covered with a polyethylene sheet were built to intercept snow and to obtain a manipulated snowpack where the temperature gradient was highly reduced. To test for possible contamination by the polyethylene sheet, we sprayed water onto the sheet and checked that no aldehydes were released. Vertical polyethylene sheets were also placed on the sides of the tables, to prevent snow from being blown off by wind. Air circulation under the tables greatly reduced the temperature gradient in the snowpack. On the tables, depth hoar did not form and snow instead evolved towards rounded shapes typical of low temperature gradient metamorphism (Colbeck, 1982; Sommerfeld, 1970). To test for possible inputs of acetaldehyde from the ground, we also placed a large polyethylene sheet on the ground and studied the snowpack that accumulated on that sheet, and in which the temperature gradient was similar to that in the natural snowpack. There were no detectable physical differences between that snowpack and the natural snowpack. We subsequently refer to the natural snowpack, the snowpack on the polyethylene sheet on the ground and the snowpack on the tables as ground, plastic, and table snowpacks, respectively.

As detailed in Taillandier et al. (2006), the ground snowpack temperature was monitored at 15 min intervals by three vertical strings of thermistors placed $7.5 \mathrm{~cm}$ apart, the lowest one being on the ground. The thermistors were fixed on a vertical post, so that their positions did not vary with time. We assume that the temperature profile in the plastic snowpack was similar to that of the ground snowpack. The temperature of the table snowpack was monitored by three thermistors. Two were placed on 11 November, one of them at the base of the snowpack and the other on the surface of the snowpack, which was then $8 \mathrm{~cm}$ thick. The third one was placed on the surface of the snow on 11 December, when the snowpack was $33 \mathrm{~cm}$ thick. The maximum thickness of the table snowpack was $45 \mathrm{~cm}$ on 23 January. Here, the thermistors were not fixed to a post, and settled with the snow. The temperature of a given layer at the time of sampling was determined by interpolation. We estimate that this resulted in a $\pm 0.5^{\circ} \mathrm{C}$ error on snow temperature. This error estimate also applies to the table snowpack because the smaller number of sensors was compensated by the lower temperature gradient.

\subsection{Snow sampling}

All snow samplings were carried out between November 2003 and April 2004 at the Large Animal Research Station (LARS: $64^{\circ} 52^{\prime} \mathrm{N}, 147^{\circ} 44^{\prime} \mathrm{W}$ ) of the University of Alaska Fairbanks. The sampling procedure has been described earlier (Hanot and Domine, 1999). Briefly, a new snow pit with vertical faces was dug for each sampling to observe the stratigraphy and identify the layers of interest. This was easier on the tables than on the ground (or plastic). On tables, the shapes of precipitating crystals remained recognizable up to several months after the fall, and some layers acted as markers that facilitated the location of layers. On the ground, the vigorous metamorphism completely transformed crystals within days at the very most, and layer boundaries shifted and often did not coincide with precipitation layers.

To minimize acetaldehyde contamination, glass vials with teflon caps were filled with ultra pure water, placed in a cooler and brought to the site. The water was emptied just before sampling, the vials were allowed to cool to ambient temperature, and were filled with snow by inserting them horizontally in the layer of interest. Polyethylene gloves were used for all stages of sampling. Density was measured by weighing a horizontal core of known volume from the layer of interest, with an accuracy of about $5 \%$ for layers thicker than $3 \mathrm{~cm}$. To detect a possible spatial heterogeneity of the snow or contamination during storage or during the analysis step, triplicate samples were always analyzed. Samples were stored at $-15^{\circ} \mathrm{C}$ until analysis.

For SSA measurements, about $100 \mathrm{~cm}^{3}$ of snow was collected in a glass vial with a stainless steel spatula thermally equilibrated with the snow, as detailed in Taillandier et al. (2006). The vial was immediately immersed in liquid nitrogen to stop metamorphism until its content was transferred to the SSA measurement container in a cold room at a temperature $<-15^{\circ} \mathrm{C}$.

\subsection{Analytical procedures}

Acetaldehyde in melted snow was measured concomitantly with formaldehyde (HCHO) by using an original method described by Houdier et al. (1999, 2000), which allows both aldehydes to react in dilute solution with a derivatizating agent, DaNSylAcetamidoOxyAmine (DNSAOA). Oxime ethers that form are subsequently separated by reverse phase HPLC and then detected by fluorescence spectroscopy. The limit of detection was lowered to $0.05 \mathrm{ppbw}$ $\left(1 \mathrm{ppbw}=1 \mathrm{ng} \mathrm{g}^{-1}\right)$ because of the very low contamination 


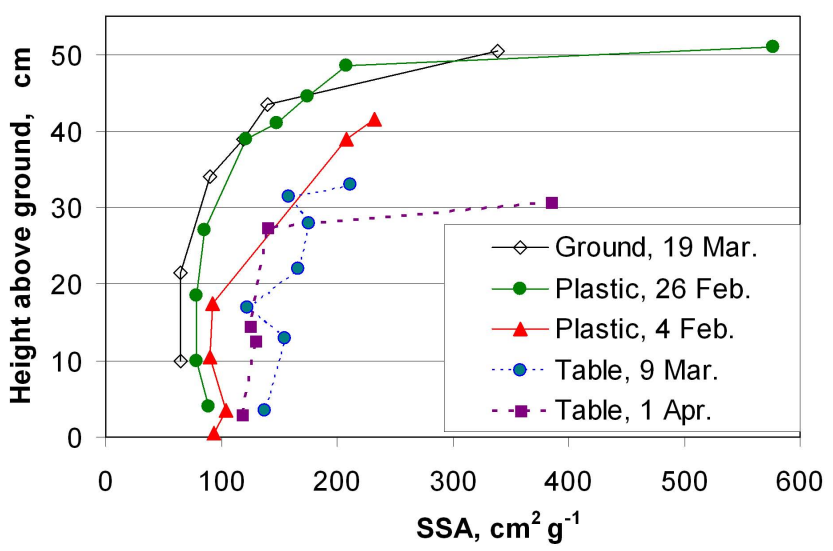

Fig. 1. Specific surface area (SSA) vertical profiles of the three snowpacks studied.

level of the DNSAOA solutions used during this campaign. Acetaldehyde concentrations reported here are generally the mean values calculated for each triplicate samples but some data were filtered as discussed in Houdier et al. (2002).

Snow SSA was determined by measuring the adsorption isotherm of methane at liquid nitrogen temperature $(77 \mathrm{~K})$. The original method is detailed in Legagneux et al. (2002), with subsequent improvements detailed in Domine et al. (2007b). A mathematical treatment was applied to the adsorption isotherm to derive the SSA. The method has a reproducibility of $6 \%$ and an accuracy better than $12 \%$.

\section{Results}

At least one weekly visit to the LARS site was made between November and April, and one or two of the three snowpacks studied (ground, plastic and tables) were sampled at each visit. In general, a complete density profile of the snowpack was measured, with a vertical resolution of $5 \mathrm{~cm}$, improved to $3 \mathrm{~cm}$ near the top. Complete aldehyde and SSA profile were measured several times, but most of the time a more limited number of identified layers was sampled. As often as possible, SSA and aldehyde concentrations were measured for the same layers, but since the objectives of our physical and chemical studies did not coincide completely, the overlap was not perfect.

\subsection{Vertical profiles of density and specific surface area}

The density of the table snowpack increased monotonically with depth and time. In early April the density increased smoothly from 0.11 to $0.27 \mathrm{~g} \mathrm{~cm}^{-3}$ from the top to the bottom of the snowpack. The density of the base of the snowpack increased from 0.13 in late November to 0.20 in late January to $0.26 \mathrm{~g} \mathrm{~cm}^{-3}$ in mid March. The density of the ground snowpack has been detailed by Taillandier et

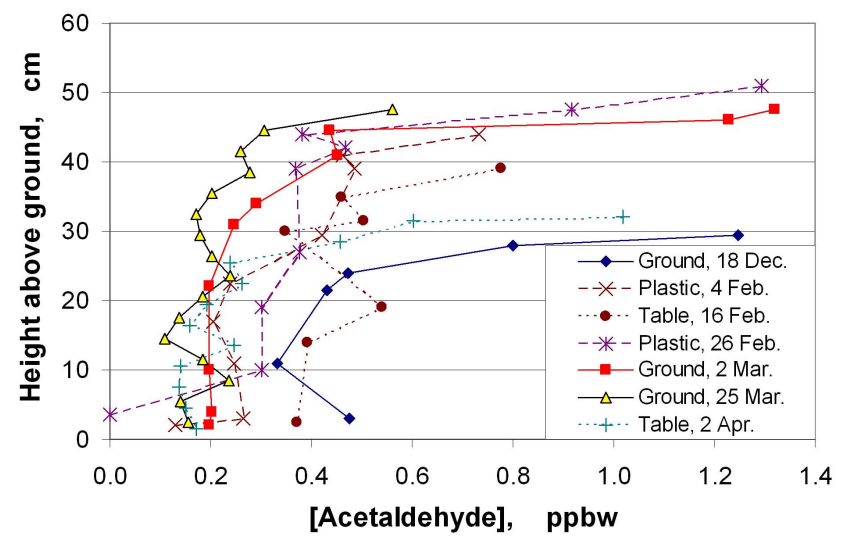

Fig. 2. Acetaldehyde vertical profiles in the three snowpacks studied.

al. (2006). Briefly, compaction of the layers due to metamorphism and to the weight of the overlying layers is compensated by the upward water vapor flux caused by the temperature gradient. The result is that, after an initial density increase to about $0.2 \mathrm{~g} \mathrm{~cm}^{-3}$, which happens in the top $20 \mathrm{~cm}$ of the snowpack, the density remained constant with time and depth around that value. The density profile was not perfectly monotonic, with density variations between 0.17 and 0.23 observed with time and depth. No significant density differences were observed between the ground and plastic snowpacks.

The SSAs of the layers of the ground snowpack have been detailed in Taillandier et al. (2006), and those of the plastic snowpack were similar. Vertical SSA profiles of the table snowpack are shown in Fig. 1, with some vertical profiles of the ground and plastic snowpacks for comparison. Figure 1 shows clearly that for layers other that the very surface ones, SSA values are greater in the table snowpack than in the ground or plastic snowpacks. This is because under temperature gradient metamorphism, the more active sublimation/condensation cycles accelerate SSA decrease (Taillandier et al., 2007). Comparison of the very surface layers is not meaningful, as the SSA value depends on the time elapsed between snowfall and sampling more than on the metamorphic regime. For the layers considered here, SSA varied between 72 and $577 \mathrm{~cm}^{2} \mathrm{~g}^{-1}$.

\subsection{Vertical profiles of acetaldehyde}

Several acetaldehyde profiles are shown in Fig. 2. An obvious observation is that their shapes appears similar to those of the SSA profiles of Fig. 1: the concentrations are high in recent snow layers, then show a fast decrease with depth, followed by a much slower decrease. In December, the concentrations in the lower half of the snowpacks were around $0.4 \mathrm{ppbw}$, and they decreased slowly to $0.2 \mathrm{ppbw}$ in March. This trend was observed in all three snowpacks. It 
is somewhat slower on the tables, but the small number of detailed vertical profiles limits the significance of this observation. The range of variation of concentrations was 0.11 to $2.57 \mathrm{ppbw}$.

\section{Discussion}

As done by Houdier et al. (2002), we first use our data to test whether the incorporation of acetaldehyde in snow is governed by adsorption or by dissolution.

\subsection{Adsorption and dissolution hypotheses}

The adsorption or dissolution of acetaldehyde in snow lead respectively to Eqs. (1) and (2), derived by Perrier et al. (2002) to predict the mole fraction of $\mathrm{CH}_{3} \mathrm{CHO}$ in snow $\left(X_{\mathrm{CH} 3 \mathrm{CHO}}\right)$ :

$X_{\mathrm{CH} 3 \mathrm{CHO}}=A \times \mathrm{SSA} \times\left(P_{\mathrm{CH} 3 \mathrm{CHO}}\right)^{1 / n} \exp \left(\frac{-\Delta H_{\mathrm{ads}}}{n R T}\right)$

$X_{\mathrm{CH} 3 \mathrm{CHO}}=A^{\prime} \times\left(P_{\mathrm{CH} 3 \mathrm{CHO}}\right)^{1 / n^{\prime}} \exp \left(\frac{\Delta H_{\text {sub }}}{n^{\prime} R T}\right)$

where $T$ is the temperature, SSA is the snow specific surface area, $P_{\mathrm{CH} 3 \mathrm{CHO}}$ is the $\mathrm{CH}_{3} \mathrm{CHO}$ partial pressure, $A$ and $A^{\prime}$ are constants, $\mathrm{n}$ and $\mathrm{n}^{\prime}$ are the number of entities created by the adsorption/dissolution of $\mathrm{CH}_{3} \mathrm{CHO}$ on/in the ice surface/volume (Thibert and Domine, 1997), $\Delta H_{\text {ads }}$ and $\Delta H_{\text {sub }}$ are the molar enthalpies of adsorption and sublimation of $\mathrm{CH}_{3} \mathrm{CHO}$ on/from ice, respectively, and $R$ is the gas constant.

The values of $P_{\mathrm{CH} 3 \mathrm{CHO}}$ that must be used to test the above equations are those in snowpack interstitial air. As mentioned in the introduction, such measurements are difficult, because with the required sampling flow rates and with current sampling technologies, snowpack air is inevitably diluted by atmospheric air, in a manner that depends on snow stratigraphy and permeability (Albert et al., 2002). As a result, it is not possible to produce reliable $P_{\mathrm{CH} 3 \mathrm{CHO}}$ snowpack values. It is tempting to use atmospheric $P_{\mathrm{CH} 3 \mathrm{CHO}}$ values as a substitute for snowpack values. However, Guimbaud et al. (2002) measured acetaldehyde at Alert both in the atmosphere $1 \mathrm{~m}$ above the snow surface and in the snowpack at several depths, with the difficulties and resulting uncertainties discussed above. They observed that snowpack and atmospheric values were significantly different. Snowpack values were lower than atmospheric ones in February, in the complete absence of sunlight, implying that the snowpack then acted as an acetaldehyde sink, whereas snowpack values were up to 8 times as high as atmospheric values in the spring ( $24 \mathrm{~h}$ daylight), implying that the snowpack was then releasing acetaldehyde to the atmosphere. Given these season-dependent differences between snowpack and overlying air composition, substituting snowpack air with overlying air analyses may lead to flawed conclusions.

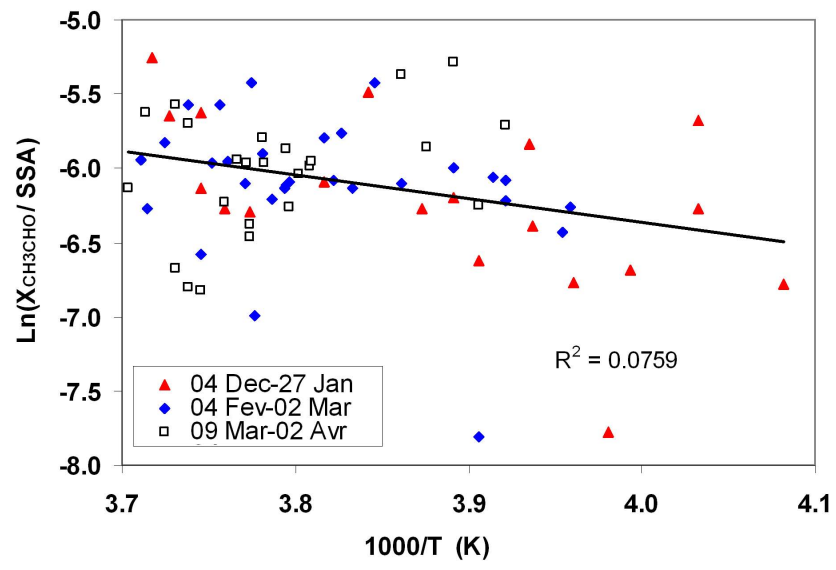

Fig. 3. Test of the possibility that acetaldehyde is adsorbed onto the surface of snow crystals, following Eq. (1). This plot assumes that $P_{\mathrm{CH} 3 \mathrm{CHO}}$ remained constant throughout the season. Different symbols for different time periods test for the possibility that $P_{\mathrm{CH} 3 \mathrm{CHO}}$ increased in snowpack air due to enhanced photochemistry with increasing sunlight.

Given the absence of $P_{\mathrm{CH} 3 \mathrm{CHO}}$ data, it is clear that attempt-

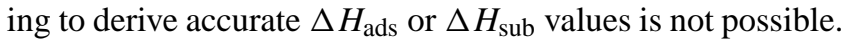
However, our approach is to observe the effect of the changes in physical and chemical variables on $X_{\mathrm{CH} 3 \mathrm{CHO}}$ to reach conclusions, and $P_{\mathrm{CH} 3 \mathrm{CHO}}$ may not be the most important source of variations. Indeed, SSA varied by a factor of $8, X_{\mathrm{CH} 3 \mathrm{CHO}}$ by a factor of 23 , and snow temperatures ranged from $0^{\circ} \mathrm{C}$ to $-37^{\circ} \mathrm{C}$. For a temperature-dependant process with an activation energy of $40 \mathrm{~kJ} \mathrm{~mol}^{-1}$, such a temperature change will produce variations of a factor of 22 in the process considered. Nevertheless, we will also test what effect expected changes in $P_{\mathrm{CH} 3 \mathrm{CHO}}$ might have on our conclusions.

We therefore tested the adsorption hypothesis (Eq. 1) by plotting $\operatorname{Ln}\left(X_{\mathrm{CH} 3 \mathrm{CHO}} / \mathrm{SSA}\right)$ vs. $1 / \mathrm{T}$ in Fig. 3 , which, as a starting working hypothesis, implicitly treats $P_{\mathrm{CH} 3 \mathrm{CHO}}$ as a constant. We also assume that $n=1$. A higher value of $n$ is expected for example in the case of dissociating acids, but $n=1$ is the most reasonable value for a non-dissociating molecule, although defects induced by the solute might produce higher $n$ values (Thibert and Domine, 1997). With $R^{2}=0.076$, and the fact that the slope of the least square fit implies a positive $\Delta H_{\text {ads }}$ value, we conclude that acetaldehyde is not adsorbed onto the surface of snow crystals.

To test the effect of variations of $P_{\mathrm{CH} 3 \mathrm{CHO}}$ on this conclusion, we have redone calculations supposing that $P_{\mathrm{CH} 3 \mathrm{CHO}}$ increases linearly by a factor of 3 between 1 December and 1 April. An increase is indeed expected with enhanced sunlight (Guimbaud et al., 2002). There is even less correlation, with $R^{2}=0.014$. If $P_{\mathrm{CH} 3 \mathrm{CHO}}$ increases by a factor of 10 , then $R^{2}=0.004$. It therefore appears very unlikely that any expected change in $P_{\mathrm{CH} 3 \mathrm{CHO}}$ could modify our conclusion that acetaldehyde is not adsorbed on snow crystals surfaces. 


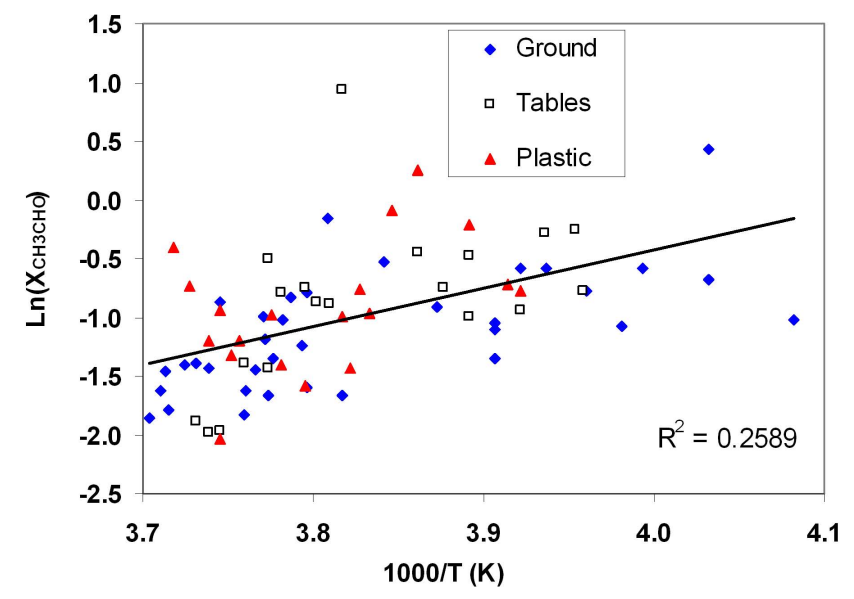

Fig. 4. Test of the possibility that acetaldehyde is dissolved at equilibrium into the ice crystal lattice, following Eq. (2). This plot assumes that $P_{\mathrm{CH} 3 \mathrm{CHO}}$ remained constant throughout the season. Different symbols for the three snowpacks used test the possibility that the intensity of sublimation/condensation cycles affected acetaldehyde-snow interactions.

To further illustrate the lack of effect of $P_{\mathrm{CH} 3 \mathrm{CHO}}$ increases with time, Fig. 3 shows different symbols for different time periods: beginning of winter (negligible sunlight), mid winter, and end of winter (about $12 \mathrm{~h}$ of daylight). The three periods do not show any significantly different trends. This adds support to our conclusion that unmonitored variations in $P_{\mathrm{CH} 3 \mathrm{CHO}}$ probably cannot reconcile the data of Fig. 3 with the adsorption hypothesis.

Likewise, one could argue that plotting data from two different metamorphic conditions (Tables with less intense metamorphism and colder temperatures and plastic and ground with intense metamorphism and warmer temperatures) led to the predominance of different physical processes, so that it is meaningless to plot all the points on one graph. We also used different symbols for the three snowpacks (not shown), and all of them showed similar trends. We therefore conclude that the shape of Fig. 3 cannot be explained by the different metamorphic conditions of the snowpacks used.

Adsorption therefore appears to be an unlikely mechanism to explain acetaldehyde incorporation in the subarctic snowpack studied. Despite the lack of data on $P_{\mathrm{CH} 3 \mathrm{CHO}}$, we can nevertheless seek a confirmation of this conclusion from recent laboratory measurements of acetaldehyde adsorption on ice, at temperatures up to $253 \mathrm{~K}$ (Petitjean et al., 2009). We nevertheless need an estimation of $P_{\mathrm{CH} 3 \mathrm{CHO}}$, which can be obtained from acetaldehyde measurements at Arctic locations. Guimbaud et al. (2002) measured atmospheric concentrations between 40 pptv (in the dark) and 100 pptv (in sunlight) at Alert, while Mabilia et al. (2007) found values around $60 \mathrm{pptv}$ in September at Ny-Ålesund, Svalbard $\left(79^{\circ} \mathrm{N}\right)$ in September. Guimbaud et al. (2002) even measured concentrations below 10 pptv in snowpack air. For our conditions of low to moderate lighting, we use a value of 50 pptv, i.e. $1.5 \times 10^{9}$ molecule $\mathrm{cm}^{-3}$ around $250 \mathrm{~K}$. With a typical snow SSA of $100 \mathrm{~cm}^{2} \mathrm{~g}^{-1}$ (Fig. 1), we predict a snow acetaldehyde concentration of $3.7 \mathrm{pptw}$ at $253 \mathrm{~K}$, i.e. 50 to 200 times lower than measured (Fig. 2). At $243 \mathrm{~K}$, a value of 3.8 pptw is found, because Petitjean et al. (2009) observed of a very weak temperature dependence of acetaldehyde adsorption on ice around $240 \mathrm{~K}$. Even with the approximations made on $P_{\mathrm{CH} 3 \mathrm{CHO}}$, on temperature and on other variables, there is no reasonable scenario that can make the laboratory data of Petitjean et al. (2009) agree with our field measurements, confirming that adsorption onto ice surfaces can only explain a negligible fraction of the acetaldehyde concentrations that we measured.

This finding is in contradiction with Couch et al. (2000). Those authors used a flow-through snow chamber filled with mid-latitude snow that was flushed with zero air and found that acetaldehyde emissions measured in effluent air followed first-order kinetics. Their conclusion was that formaldehyde, acetaldehyde and acetone were adsorbed onto the surface of snow crystals. While conditions in Michigan could have been different, another possibility not envisaged by those authors was that zero air sublimed snow, releasing carbonyls in solid solution in the ice crystalline lattice. This would also have shown first-order kinetics. Another possibility is the release of carbonyls contained in organic aerosols, which we explore later.

In Fig. 4, we tested the dissolution hypothesis, following Eq. (2), by plotting $\operatorname{Ln}\left(X_{\mathrm{CH} 3 \mathrm{CHO}}\right)$ vs. $1 / \mathrm{T}$, again implicitly treating $P_{\mathrm{CH} 3 \mathrm{CHO}}$ as a constant. The correlation is poor, $R^{2}=0.259$. As with the adsorption hypothesis, we explored the effect of an increase in $P_{\mathrm{CH}} \mathrm{CHO}$ by factors of 3 and 10 on the correlation, and $R^{2}$ changed to 0.2766 and 0.1483 . We also examined the possibility of temporal trends and the influence of the snowpack type. As in Fig. 3, the three time periods examined showed similar trends. Figure 4 also shows that the three snowpacks studied showed similar trends. For species that form a solid solution with ice, as is thought to be the case for $\mathrm{HCHO}, \mathrm{HNO}_{3}$ and $\mathrm{HCl}$ (Burkhart et al., 2002; Domine and Thibert, 1996; Perrier et al., 2003), it was found that precipitating snow crystals were out of equilibrium with surface atmospheric composition (Domine et al., 1995; Jacobi et al., 2002). Equilibration can take place by solid state diffusion on the timescale of days to weeks, even months, or by sublimation/condensation, a potentially faster process (Domine and Thibert, 1996). If acetaldehyde forms a solid solution with ice, it is then reasonable to expect different trends in Fig. 4 between the table snowpack and the other snowpacks. Indeed, the vigorous sublimation/condensation cycles in the presence of a high temperature gradient allow the rapid release of species forming a solid solution with ice. Observations of snow crystals (Taillandier et al., 2006) indicate that most of the crystals mass is sublimated in a few days at the most. On the contrary, in the absence of significant 
temperature gradients, the shape of precipitating crystals was still recognizable after several months, showing that solid state diffusion, rather that sublimation, was needed to release dissolved species. It would need an unlikely coincidence for two such different processes to yield similar trends in Fig. 4. Given this mechanistic argument and the poor correlation, we believe that it is unlikely that most of the acetaldehyde measured is in the form of a solid solution with ice. Furthermore, if we assume that $n^{\prime}=1$ in Eq. (2) because acetaldehyde is not expected to dissociate, and if $P_{\mathrm{CH} 3 \mathrm{CHO}}$ is assumed constant, we obtain $\Delta H_{\text {sub }}=27 \mathrm{~kJ} \mathrm{~mol}^{-1}$, much lower than values measured in liquid water, $52.1 \mathrm{~kJ} \mathrm{~mol}^{-1}$ by Betterton and Hoffmann (1988) and $47.4 \mathrm{~kJ} \mathrm{~mol}^{-1}$ by Michelsen et al. (2004). Studies on $\mathrm{HCl}$ and $\mathrm{HNO}_{3}$ (Thibert and Domine, 1997, 1998) have shown that the heats of sublimation from ice and water were similar for both these acids, and we therefore do not expect such a difference for acetaldehyde. We note, however, that if $n^{\prime}=2, \Delta H_{\text {sub }}=54 \mathrm{~kJ} \mathrm{~mol}^{-1}$, a reasonable value. The value $n^{\prime}=2$ is possible if the incorporation of acetaldehyde in ice produces a defect, a process which cannot be ruled out given the large size of the molecule.

With the data obtained, we cannot conclude with as much confidence as in the adsorption hypothesis that acetaldehyde does not form a solid solution with ice in equilibrium with snowpack air in subarctic Alaskan snow, but it is clear that our observations are not well explained by this incorporation mechanism. From their data obtained at Alert, Houdier et al. (2002) also considered the possibility that a solid solution formed, but that its composition would be dictated by condensation kinetics rather than equilibrium. This was also investigated but given the differences in temperature between the different snowpacks, this hypothesis could rapidly be ruled out. If acetaldehyde is neither adsorbed on nor dissolved in ice, we have to consider the possibility that it is contained in another phase, most likely organic aerosols.

\subsection{Incorporation of acetaldehyde in organic particles}

Acetaldehyde is an extremely volatile compound. Its saturating vapor pressure is $10 \mathrm{kPa}$ at $-29.4^{\circ} \mathrm{C}$ (Lide, 1997). At first sight, it therefore appears unlikely that it can be contained in appreciable amounts in organic aerosols. However, organic aerosols are complex media, and it is probably reasonable to state that the understanding of their composition and structure its still in its infancy (Decesari et al., 2006; Tabazadeh, 2005). It is possible that acetaldehyde is dissolved in a concentrated aqueous phase surrounded by organic molecules that prevent its evaporation (Gill et al., 1983), or that it is physically trapped in complex macromolecular networks such as humic-like substances (Decesari et al., 2006). Given our poor understanding of these hypothetical processes, a quantitative discussion is not possible.

Another possibility, already suggested by Houdier et al. (2002), is that a precursor within organic aerosols produces acetaldehyde when the snow is melted for analysis.
This idea has recently gained some strength, as van Pinxteren et al. (2005) and Li et al. (2008) measured acetaldehyde and other carbonyls in cloud droplets and in the gas phase and concluded from the unexpectedly high concentrations that their carbonyl signals may have been caused by the dissociation of precursors, when the chemical properties of the solution was changed for analysis.

Potential aldehyde precursors are many. Aldehydes are among precursors of atmospheric organic aerosols, as they can polymerize to eventually form, after other reactions, complex macromolecular networks called HULIS (HUmicLIke Substances; Graber and Rudich, 2006) which contain chemical structures such as hemi-acetals, acetals and aromatics (Jang et al., 2002; Kalberer et al., 2004; Noziere and Cordova, 2008; Noziere et al., 2009). Recent studies have shown that amino acids could also catalyze the polymerization of aldehydes, through aldol condensation and Mannich reactions (Noziere and Cordova, 2008). The detection of those complex chemical structures has been hampered by the fact that when placed in solution, they can easily reform their original aldehydes, leading to a positive artifact in aldehyde concentrations (Jang et al., 2002). This is illustrated by the fact that acid hydrolysis of 2,4-pentadione formed acetone and acetaldehyde (Noziere and Riemer, 2003). The photochemistry of HULIS contained in organic particles in the snow may also produce acetaldehyde (Guzman et al., 2007), which may remain trapped within the complex macromolecular structures and be released upon melting and analysis.

Although the subject has been little studied, biological compounds or even live and dead microorganisms, which are commonly found in atmospheric aerosols (Ariya and Amyot, 2004), may also be involved in the formation of aldehydes when snow is melted. Acetaldehyde is produced by microorganisms during glycolysis, by the decarboxylation of pyruvate (King and Cheldelin, 1954). Acetaldehyde can then be trapped in the complex organic molecular assemblages formed by dead of living cells, and this compound can be released to the solution upon snowmelt. While glycolysis is an anaerobic process, studies have shown (Monrozier et al., 1993) or suggested (Amoroso et al., 2009) that oxic and anoxic environments could coexist within submillimetric distances in media such as soils and snow, so its presence here is a possibility, although clearly speculative at this point.

Biological precursors may also produce acetaldehyde when placed in solution. Plasmalogens are glycerolipids where an ester bond has been replaced with a vinylether bond that readily opens under acidic conditions to form an aldehyde (Snyder, 1999; Wood and Healy, 1970). Plasmalogens are frequent in bacterial and archaeal membranes (Snyder, 1999) and these are found in soils and in aerosol particles (Ariya et al., 2009; Gattinger et al., 2003). Producing acetaldehyde would require the existence of plasmalogens with 2-carbon chains, while these molecules usually have much longer chains (Koga and Morii, 2007). However, the analytical methods commonly used to analyze etherlipids (Gattinger 


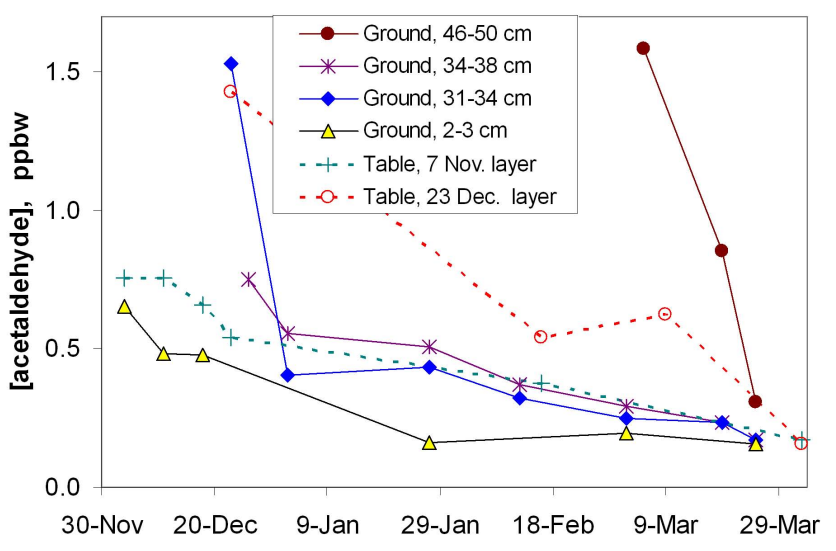

Fig. 5. Evolution of the concentration of acetaldehyde in some of the snow layers studied. For the ground snowpack, given precipitated layers could not be followed because layer boundaries were erased by metamorphism, and the concentration at a given height is then plotted. For the Table snowpack, layers remained identifiable.

et al., 2003) would not be able to detect $\mathrm{C} 2$ chains, so that their presence cannot be ruled out. It is also possible that the long isoprenoid side chains found both in bacteria and archaea (Koga and Morii, 2007) are vulnerable to degradation and do produce shorter chains aldehydes. While this suggestion clearly remains speculative, we suggest here that the chemical complexity of microorganisms may lead to acetaldehyde production in solution, but the investigation of this topic is clearly beyond our current scope.

To sum up this last possibility for acetaldehyde incorporation in snow, established and potential precursors to acetaldehyde in organic aerosols therefore abound. Proving convincingly and quantitatively that these are responsible for our acetaldehyde signal will require complex analyses and laboratory experiments beyond the scope of this paper. However, to bring preliminary support to our suggestion, we tested the possibility of acetaldehyde release from an acetal placed with DNSAOA in a dilute solution. We chose the commercially available acetaldehyde-di-n-hexyl acetal ( (hexO) $)_{2} \mathrm{CHCH}_{3}$ ) as a model of acetal of $\mathrm{CH}_{3} \mathrm{CHO}$. A solution of (hexO) $)_{2} \mathrm{CHCH}_{3}\left(9.10^{-7} \mathrm{M}\right)$ was thus allowed to react with a DNSAOA $\left(5.2 .10^{-6} \mathrm{M}\right)$ aqueous solution. At completion, $64 \%$ of the acetal had reacted to produce $\mathrm{CH}_{3} \mathrm{CHO}$. Acetals generally hydrolyze under acidic catalysis to reversibly form the aldehydes from which they were synthesized (Reaction R1). In our analytical procedure, no acid catalyst was added so that the $\mathrm{pH}$ of the unbuffered reacting solution most likely remains close to the $\mathrm{CO}_{2}$ dissolution equilibrium $\mathrm{pH}$ (about 5.5). If acid catalysis cannot be invoked in this test, it is likely that the equilibrium in Reaction (R1) was strongly displaced to the right due to the reaction between DNSAOA and $\mathrm{CH}_{3} \mathrm{CHO}$ (Reaction $\mathrm{R} 2$ ).

$(\text { hexO) })_{2} \mathrm{CHCH}_{3}+\mathrm{H}_{2} \mathrm{O} \leftrightarrow \mathrm{CH}_{3} \mathrm{CHO}+2 \mathrm{HexOH}$
$\mathrm{DNSAOA}+\mathrm{CH}_{3} \mathrm{CHO} \leftrightarrow \mathrm{DNSAOA}-\mathrm{CH}_{3} \mathrm{CHO}+\mathrm{H}_{2} \mathrm{O}$

We have no proof that acetals of acetaldehyde were present in aerosol particles trapped in the snowpacks studied, but these preliminary results add credence to our hypothesis and suggest directions for further investigations.

\subsection{Evolution with time and atmospheric impact}

In all snowpacks studied, the general trend is that $X_{\mathrm{CH} 3 \mathrm{CHO}}$ decreases slowly over time, with a factor of two to six decrease in about three months (Fig. 5). Following the hypothesis that acetaldehyde is in organic aerosols, this can be interpreted in two ways. If acetaldehyde is dissolved or trapped within aerosol particles, this can be simply interpreted by the slow release of acetaldehyde by diffusion out of the particles. If acetaldehyde is present as heavier precursors, then the decrease with time suggests that the precursors decompose slowly. Both processes will be facilitated by the fact that as a snow layer is covered by subsequent precipitation, its temperature increases because it is sheltered from the cold atmosphere (Taillandier et al., 2006). In any case, Fig. 5 indicates that the kinetics of these processes are slow. They therefore cannot be easily studied in the laboratory and their understanding will require specific experiments.

If the decrease of the acetaldehyde signal in snow shown in Fig. 5 translates into a snow to atmosphere transfer, then the flux can be calculated. Assuming that the concentration of acetaldehyde in a snowpack $45 \mathrm{~cm}$ thick of density $0.2 \mathrm{~g} \mathrm{~cm}^{-3}$ decreases from 1 to $0.2 \mathrm{ppbw}$ (Fig. 2) over a five months period, and that the acetaldehyde released mixes into a $300 \mathrm{~m}$-thick boundary layer, then the increase in atmospheric concentration will be $0.8 \mathrm{pptv}$ per day. If atmospheric concentrations are around $50 \mathrm{pptv}$, then this snowpack flux may represent a contribution to the atmospheric acetaldehyde budget that is worth considering in models, although a quantification of its importance is beyond our current scope. Photolysis of acetaldehyde and subsequent reaction with $\mathrm{NO}_{2}$ can lead to formation of peroxyacetyl nitrate (PAN), which is one of the dominant $\mathrm{NO}_{\mathrm{y}}$ species at high latitudes during winter (Bottenheim et al., 1986). The snow-to-atmosphere flux of acetaldehyde hypothesized here may therefore impact Arctic $\mathrm{NO}_{\mathrm{y}}$ chemistry.

\section{Conclusions}

For thermodynamic and kinetic calculations, and to fully understand snowpack photochemistry and air-snow exchanges of reactive molecules, the location (and hence heterogeneous reactivity) of molecules detected in snow must be elucidated. By performing a season-long study of acetaldehyde concentrations in snow, we conclude that acetaldehyde is not adsorbed onto snow crystal surfaces, and that it is for the most part probably not dissolved within snow crystals, whether at equilibrium or not. We are able to propose this conclusion 
despite the fact that we did not measure $P_{\mathrm{CH} 3 \mathrm{CHO}}$ in snowpack air, a delicate an risky enterprise. This is because we constrained other variables by performing a detailed study of snowpack physical properties, and in particular because we measured snow SSA. Another useful addition was the study of a manipulated snowpack where we imposed a drastically different metamorphic regime that led to different physical transformations and properties in the snowpack.

From our data and analysis, the most logical interpretation is that acetaldehyde is mostly contained in organic aerosol particles located within the snowpack. Acetaldehyde may either be physically trapped within particles or could be produced from organic (abiotic and/or biological) precursors contained in organic aerosols. At this stage however, our understanding of the relevant physical and chemical processes is insufficient for a detailed and quantitative interpretation of acetaldehyde profiles. In particular, the rapid decrease in acetaldehyde concentrations after snow deposition is not fully explained. Depolymerisation, release from microorganisms, or evaporation are possibilities. Progress will require a better characterization of the structure, composition and reactivity of organic matter in aerosols. Furthermore, we cannot entirely rule out that a fraction of the acetaldehyde is dissolved in the ice lattice, but this will need confirmation by adequate laboratory experiments.

Our results imply that analyses of acetaldehyde in snow cannot be used to understand snow-atmosphere equilibria. The results of Li et al. (2008) implicitly lead to the same conclusion for cloud droplet-atmosphere equilibria. With current analytical techniques, we propose that the acetaldehyde signal in snow and water contains information on the structure and composition of organic matter present in those phases. The interpretation of this signal will require further studies.

Acknowledgements. FD and AST thank the Geophysical Institute, University of Alaska Fairbanks, for hosting them during this study, while they were supported by CNRS and the French Ministry of Research. Research funds for this project were supplied to FD, AST and WRS by the Chapman Chair, held by Professor Norbert Untersteiner, and by IARC, and to $\mathrm{SH}$ by the French Polar Institute (IPEV), under the FAMAS program. We gratefully thank Bill Hauer for proposing the LARS site for this study and for assistance throughout the field work. Thomas A. Douglas and Matthew Sturm kindly provided the temperature data in the ground snowpack. We also thank Tom Trainor for providing laboratory space for aldehyde measurements at the University of Alaska Fairbanks. Insightful discussions with Barbara Nozière on aldehyde chemical reactions in solutions, and with Jean-Marc Bonneville and colleagues on the possible biological origin of acetaldehyde in snow are acknowledged.

Edited by: V. F. McNeill

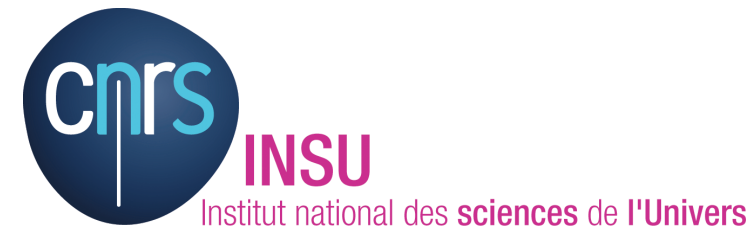

The publication of this article is financed by CNRS-INSU.

\section{References}

Albert, M. R., Grannas, A. M., Bottenheim, J., Shepson, P. B., and Perron, F. E.: Processes and properties of snow-air transfer in the high Arctic with application to interstitial ozone at Alert, Canada, Atmos. Environ., 36, 2779-2787, 2002.

Amoroso, A., Domine, F., Esposito, G., Morin, S., Savarino, J., Nardino, M., Montagnoli, M., Bonneville, J.-M., Clement, J.C., Ianniello, A., and Beine, H. J.: Microorganisms in Dry Polar Snow Are Involved in the Exchanges of Reactive Nitrogen Species with the Atmosphere, Environ. Sci. Technol., 44, 714719, 2009.

Ariya, P. A. and Amyot, M.: New Directions: The role of bioaerosols in atmospheric chemistry and physics, Atmos. Environ., 38, 1231-1232, doi:10.1016/j.atmosenv.2003.12.006, 2004.

Ariya, P. A., Sun, J., Eltouny, N. A., Hudson, E. D., Hayes, C. T., and Kos, G.: Physical and chemical characterization of bioaerosols - Implications for nucleation processes, Int. Rev. Phys. Chem., 28, 1-32, doi:10.1080/01442350802597438, 2009.

Barrie, L. A., Bottenheim, J. W., Schnell, R. C., Crutzen, P. J., and Rasmussen, R. A.: Ozone destruction and photochemicalreactions at polar sunrise in the lower arctic atmosphere, Nature, 334, 138-141, 1988.

Betterton, E. A. and Hoffmann, M. R.: Henry law constants of some environmentally important aldehydes, Environ. Sci. Technol., 22, 1415-1418, 1988.

Bottenheim, J. W., Gallant, A. G., and Brice, K. A.: Measurements of $\mathrm{NO}_{\mathrm{y}}$ species and $\mathrm{O}_{3}$ at 82-degrees-N latitude, Geophys. Res. Lett., 13, 113-116, 1986.

Boudries, H., Bottenheim, J. W., Guimbaud, C., Grannas, A. M., Shepson, P. B., Houdier, S., Perrier, S., and Domine, F.: Distribution and trends of oxygenated hydrocarbons in the high Arctic derived from measurements in the atmospheric boundary layer and interstitial snow air during the ALERT2000 field campaign, Atmos. Environ., 36, 2573-2583, 2002.

Burkhart, J. F., Hutterli, M. A., and Bales, R. C.: Partitioning of formaldehyde between air and ice at $-35^{\circ} \mathrm{C}$ to $-5^{\circ} \mathrm{C}$, Atmos. Environ., 36, 2157-2163, 2002.

Colbeck, S. C.: An overview of seasonal snow metamorphism, Rev. Geophys., 20, 45-61, 1982.

Colbeck, S. C.: The layered character of snow covers, Rev. Geophys., 29, 81-96, 1991.

Couch, T. L., Sumner, A. L., Dassau, T. M., Shepson, P. B., and Honrath, R. E.: An investigation of the interaction of carbonyl compounds with the snowpack, Geophys. Res. Lett., 27, 22412244, 2000.

Decesari, S., Fuzzi, S., Facchini, M. C., Mircea, M., Emblico, L., Cavalli, F., Maenhaut, W., Chi, X., Schkolnik, G., Falkovich, A., Rudich, Y., Claeys, M., Pashynska, V., Vas, G., Kourtchev, I., Vermeylen, R., Hoffer, A., Andreae, M. O., Tagliavini, E., 
Moretti, F., and Artaxo, P.: Characterization of the organic composition of aerosols from Rondônia, Brazil, during the LBASMOCC 2002 experiment and its representation through model compounds, Atmos. Chem. Phys., 6, 375-402, 2006, http://www.atmos-chem-phys.net/6/375/2006/.

Dibb, J. E. and Arsenault, M.: Shouldn't snowpacks be sources of monocarboxylic acids?, Atmos. Environ., 36, 2513-2522, 2002.

Domine, F., Thibert, E., Silvente, E., Legrand, M., and Jaffrezo, J. L.: Determining past atmospheric $\mathrm{HCl}$ mixing ratios from ice core analyses, J. Atmos. Chem., 21, 165-186, 1995.

Domine, F. and Thibert, E.: Mechanism of incorporation of trace gases in ice grown from the gas phase, Geophys. Res. Lett., 23, 3627-3630, 1996.

Domine, F., Cabanes, A., and Legagneux, L.: Structure, microphysics, and surface area of the Arctic snowpack near Alert during the ALERT 2000 campaign, Atmos. Environ., 36, 27532765, 2002.

Domine, F. and Shepson, P. B.: Air-snow interactions and atmospheric chemistry, Science, 297, 1506-1510, 2002.

Domine, F., Taillandier, A. S., Houdier, S., Parrenin, F., Simpson, W. R., and Douglas, T. A.: Interactions between snow metamorphism and climate: Physical and chemical aspects, in: Physics and Chemistry of Ice, edited by: Kuhs, W. F., Royal Society of Chemistry, UK, Cambridge, 27-46, 2007a.

Domine, F., Taillandier, A. S., and Simpson, W. R.: A parameterization of the specific surface area of seasonal snow for field use and for models of snowpack evolution, J. Geophys. Res.-Earth, 112, F02031, doi:10.1029/2006jf000512, 2007b.

Domine, F., Albert, M., Huthwelker, T., Jacobi, H.-W., Kokhanovsky, A. A., Lehning, M., Picard, G., and Simpson, W. R.: Snow physics as relevant to snow photochemistry, Atmos. Chem. Phys., 8, 171-208, 2008, http://www.atmos-chem-phys.net/8/171/2008/.

Gattinger, A., Gunther, A., Schloter, M., and Munich, J. C.: Characterisation of Archaea in soils by polar lipid analysis, Acta Biotechnol., 23, 21-28, 2003.

Gill, P. S., Graedel, T. E., and Weschler, C. J.: Organic films on atmospheric aerosol-particles, fog droplets, cloud droplets, raindrops, and snowflakes, Rev. Geophys., 21, 903-920, 1983.

Graber, E. R. and Rudich, Y.: Atmospheric HULIS: How humiclike are they? A comprehensive and critical review, Atmos. Chem. Phys., 6, 729-753, 2006, http://www.atmos-chem-phys.net/6/729/2006/.

Grannas, A. M., Shepson, P. B., Guimbaud, C., Sumner, A. L., Albert, M., Simpson, W., Domine, F., Boudries, H., Bottenheim, J., Beine, H. J., Honrath, R., and Zhou, X. L.: A study of photochemical and physical processes affecting carbonyl compounds in the Arctic atmospheric boundary layer, Atmos. Environ., 36, 2733-2742, 2002.

Grannas, A. M., Shepson, P. B., and Filley, T. R.: Photochemistry and nature of organic matter in Arctic and Antarctic snow, Global Biogeochem. Cy., 18, GB1006, doi:10.1029/2003gb002133, 2004.

Grannas, A. M., Jones, A. E., Dibb, J., Ammann, M., Anastasio, C., Beine, H. J., Bergin, M., Bottenheim, J., Boxe, C. S., Carver, G., Chen, G., Crawford, J. H., Dominé, F., Frey, M. M., Guzmán, M. I., Heard, D. E., Helmig, D., Hoffmann, M. R., Honrath, R. E., Huey, L. G., Hutterli, M., Jacobi, H. W., Klán, P., Lefer, B., McConnell, J., Plane, J., Sander, R., Savarino, J., Shepson, P.
B., Simpson, W. R., Sodeau, J. R., von Glasow, R., Weller, R., Wolff, E. W., and Zhu, T.: An overview of snow photochemistry: evidence, mechanisms and impacts, Atmos. Chem. Phys., 7, 4329-4373, 2007,

http://www.atmos-chem-phys.net/7/4329/2007/.

Guimbaud, C., Grannas, A. M., Shepson, P. B., Fuentes, J. D., Boudries, H., Bottenheim, J. W., Domine, F., Houdier, S., Perrier, S., Biesenthal, T. B., and Splawn, B. G.: Snowpack processing of acetaldehyde and acetone in the Arctic atmospheric boundary layer, Atmos. Environ., 36, 2743-2752, 2002.

Guzman, M. I., Hoffmann, M. R., and Colussi, A. J.: Photolysis of pyruvic acid in ice: Possible relevance to $\mathrm{CO}$ and $\mathrm{CO}_{2}$ ice core record anomalies, J. Geophys. Res.-Atmos., 112, D10123, doi:10.1029/2006jd007886, 2007.

Hanot, L. and Domine, F.: Evolution of the surface area of a snow layer, Environ. Sci. Technol., 33, 4250-4255, 1999.

Houdier, S., Legrand, M., Boturyn, D., Croze, S., Defrancq, E., and Lhomme, J.: A new fluorescent probe for sensitive detection of carbonyl compounds, Anal. Chim. Acta, 382, 253-263, 1999.

Houdier, S., Perrier, S., Defrancq, E., and Legrand, M.: A new fluorescent probe for sensitive detection of carbonyl compounds: sensitivity improvement and application to environmental water samples, Anal. Chim. Acta, 412, 221-233, 2000.

Houdier, S., Perrier, S., Domine, F., Cabanes, A., Legagneux, L., Grannas, A. M., Guimbaud, C., Shepson, P. B., Boudries, H., and Bottenheim, J. W.: Acetaldehyde and acetone in the Arctic snowpack during the ALERT2000 campaign, Snowpack composition, incorporation processes and atmospheric impact, Atmos. Environ., 36, 2609-2618, 2002.

Hutterli, M. A., Rothlisberger, R., and Bales, R. C.: Atmosphereto-snow-to-firn transfer studies of $\mathrm{HCHO}$ at Summit, Greenland, Geophys. Res. Lett., 26, 1691-1694, 1999.

Hutterli, M. A., Bales, R. C., McConnell, J. R., and Stewart, R. W.: HCHO in Antarctic snow: Preservation in ice cores and air-snow exchange, Geophys. Res. Lett., 29, 1235, doi:10.1029/2001GL014256, 2002.

Jacobi, H. W., Frey, M. M., Hutterli, M. A., Bales, R. C., Schrems, O., Cullen, N. J., Steffen, K., and Koehler, C.: Measurements of hydrogen peroxide and formaldehyde exchange between the atmosphere and surface snow at Summit, Greenland, Atmos. Environ., 36, 2619-2628, 2002.

Jang, M. S., Czoschke, N. M., Lee, S., and Kamens, R. M.: Heterogeneous atmospheric aerosol production by acid-catalyzed particle-phase reactions, Science, 298, 814-817, 2002.

Kalberer, M., Paulsen, D., Sax, M., Steinbacher, M., Dommen, J., Prevot, A. S. H., Fisseha, R., Weingartner, E., Frankevich, V., Zenobi, R., and Baltensperger, U.: Identification of polymers as major components of atmospheric organic aerosols, Science, 303, 1659-1662, 2004.

King, T. E. and Cheldelin, V. H.: Pyruvic carboxylase of acetobacter-suboxydans, J. Biol. Chem., 208, 821-831, 1954.

Koga, Y. and Morii, H.: Biosynthesis of ether-type polar lipids in archaea and evolutionary considerations, Microbiol. Mol. Biol. R., 71, 97-120, doi:10.1128/mmbr.00033-06, 2007.

Lary, D. J. and Shallcross, D. E.: Central role of carbonyl compounds in atmospheric chemistry, J. Geophys. Res.-Atmos., 105, 19771-19778, 2000.

Legagneux, L., Cabanes, A., and Domine, F.: Measurement of the specific surface area of 176 snow samples using methane 
adsorption at $77 \mathrm{~K}$, J. Geophys. Res.-Atmos., 107, 4335, doi:10.1029/2001jd001016, 2002.

Li, S. M., Macdonald, A. M., Leithead, A., Leaitch, W. R., Gong, W. M., Anlauf, K. G., Toom-Sauntry, D., Hayden, K., Bottenheim, J., and Wang, D.: Investigation of carbonyls in cloudwater during ICARTT, J. Geophysi. Res.-Atmos., 113, D17206, doi:10.1029/2007jd009364, 2008.

Mabilia, R., Di Palo, V., Cassardo, C., Ciuchini, C., Pasini, A., and Possanzini, M.: Measurements of lower carbonyls and hydrocarbons at Ny-Alesund, svalbard, Annali Di Chimica, 97, 10271037, 2007.

Mauldin, R. L., Eisele, F. L., Tanner, D. J., Kosciuch, E., Shetter, R., Lefer, B., Hall, S. R., Nowak, J. B., Buhr, M., Chen, G., Wang, P., and Davis, D.: Measurements of $\mathrm{OH}, \mathrm{H}_{2} \mathrm{SO}_{4}$, and MSA at the South Pole during ISCAT, Geophys. Res. Lett., 28, 3629-3632, 2001.

Michelsen, R. R., Ashbourn, S. F. M., and Iraci, L. T.: Dissolution, speciation, and reaction of acetaldehyde in cold sulfuric acid, J. Geophys. Res.-Atmos., 109, D23205, doi:10.1029/2004jd005041, 2004.

Monrozier, L. J., Guez, P., Chalamet, A., Bardin, R., Martins, J., and Gaudet, J. P.: Distribution of micro-organisms and fate of xenobiotic molecules in unsaturated soil environments, Sci. Total Environ., 136, 121-133, 1993.

Noziere, B. and Riemer, D. D.: The chemical processing of gas-phase carbonyl compounds by sulfuric acid aerosols-2,4pentanedione, Atmos. Environ., 37, 841-851, 2003.

Noziere, B. and Cordova, A.: A kinetic and mechanistic study of the amino acid catalyzed aldol condensation of acetaldehyde in aqueous and salt solutions, J. Phys. Chem. A, 112, 2827-2837, doi:10.1021/jp7096845, 2008.

Noziere, B., Dziedzic, P., and Cordova, A.: Products and Kinetics of the Liquid-Phase Reaction of Glyoxal Catalyzed by Ammonium Ions $\left(\mathrm{NH}_{4}^{+}\right)$, J. Phys. Chem. A, 113, 231-237, doi:10.1021/jp8078293, 2009.

Perrier, S., Houdier, S., Domine, F., Cabanes, A., Legagneux, L., Sumner, A. L., and Shepson, P. B.: Formaldehyde in Arctic snow. Incorporation into ice particles and evolution in the snowpack, Atmos. Environ., 36, 2695-2705, 2002.

Perrier, S., Sassin, P., and Domine, F.: Diffusion and solubility of HCHO in ice: preliminary results, Can. J. Phys., 81, 319-324, doi:10.1139/p03-033, 2003.

Petitjean, M., Mirabel, P., and Le Calve, S.: Uptake Measurements of Acetaldehyde on Solid Ice Surfaces and on Solid/Liquid Supercooled Mixtures Doped with $\mathrm{HNO}_{3}$ in the Temperature Range 203-253 K, J. Phys. Chem. A, 113, 5091-5098, 2009.

Shepson, P. B., Sirju, A. P., Hopper, J. F., Barrie, L. A., Young, V., Niki, H., and Dryfhout, H.: Sources and sinks of carbonyl compounds in the arctic ocean boundary layer: Polar ice floe experiment, J. Geophys. Res.-Atmos., 101, 21081-21089, 1996.

Snyder, F.: The ether lipid trail: a historical perspective, Bba.-Mol. Cell Biol. L., 1436, 265-278, 1999.
Sokolov, O. and Abbatt, J. P. D.: Adsorption to ice of nalcohols (ethanol to 1-hexanol), acetic acid, and hexanal, J. Phys. Chem. A, 106, 775-782, doi:10.1021/jp013291m, 2002.

Sommerfeld, R. A. and LaChapelle, E.: The classification of snow metamorphism, J. Glaciol., 9, 3-17, 1970.

Sturm, M. and Johnson, J. B.: Natural-convection in the sub-arctic snow cover, J. Geophys. Res.-Solid, 96, 11657-11671, 1991.

Sturm, M., Holmgren, J., and Liston, G. E.: A seasonal snow cover classification-system for local to global applications, J. Climate, 8, 1261-1283, 1995.

Sturm, M. and Benson, C. S.: Vapor transport, grain growth and depth-hoar development in the subarctic snow, J. Glaciol., 43, 42-59, 1997.

Sumner, A. L. and Shepson, P. B.: Snowpack production of formaldehyde and its effect on the Arctic troposphere, Nature, 398, 230-233, 1999.

Swanson, A. L., Blake, N. J., Dibb, J. E., Albert, M. R., Blake, D. R., and Rowland, F. S.: Photochemically induced production of $\mathrm{CH}_{3} \mathrm{Br}, \mathrm{CH}_{3} \mathrm{I}, \mathrm{C}_{2} \mathrm{H}_{5} \mathrm{I}$, ethene, and propene within surface snow at Summit, Greenland, Atmos. Environ., 36, 2671-2682, 2002.

Tabazadeh, A.: Organic aggregate formation in aerosols and its impact on the physicochemical properties of atmospheric particles, Atmos. Environ., 39, 5472-5480, doi:10.1016/j.atmosenv.2005.05.045, 2005.

Taillandier, A. S., Domine, F., Simpson, W. R., Sturm, M., Douglas, T. A., and Severin, K.: Evolution of the snow area index of the subarctic snowpack in central Alaska over a whole season, Consequences for the air to snow transfer of pollutants, Environ. Sci. Technol., 40, 7521-7527, doi:10.1021/es060842j, 2006.

Taillandier, A. S., Domine, F., Simpson, W. R., Sturm, M., and Douglas, T. A.: Rate of decrease of the specific surface area of dry snow: Isothermal and temperature gradient conditions, J. Geophys. Res.-Earth, 112, F03003, doi:10.1029/2006jf000514, 2007.

Thibert, E. and Domine, F.: Thermodynamics and kinetics of the solid solution of $\mathrm{HCl}$ in ice, J. Phys. Chem. B, 101, 3554-3565, 1997.

Thibert, E. and Domine, F.: Thermodynamics and kinetics of the solid solution of $\mathrm{HNO}_{3}$ in ice, J. Phys. Chem. B, 102, 4432 4439, 1998.

van Pinxteren, D., Plewka, A., Hofmann, D., Muller, K., Kramberger, H., Svrcina, B., Bachmann, K., Jaeschke, W., Mertes, S., Collett, J. L., and Herrmann, H.: Schmucke hill cap cloud and valley stations aerosol characterisation during FEBUKO (II): Organic compounds, Atmos. Environ., 39, 43054320, doi:10.1016/j.atmosenv.2005.02.014, 2005.

Wood, R. and Healy, K.: Liberation of aldehydes from alk-1-enyl glyceryl ethers by acid hydrolysis, Lipids, 5, 661-663, 1970.

Yang, J., Honrath, R. E., Peterson, M. C., Dibb, J. E., Sumner, A. L., Shepson, P. B., Frey, M., Jacobi, H. W., Swanson, A., and Blake, N.: Impacts of snowpack emissions on deduced levels of $\mathrm{OH}$ and peroxy radicals at Summit, Greenland, Atmos. Environ., 36, 2523-2534, 2002. 